Radiometric Scanning of

Collections of Keweenawan

Rocks of the Michigan

Copper District

Trace Elements Memorandum Report 34

UNITED STATES DEPARTMENT OF THE INTERIOR GEOLOGICAL SURVEY 



\section{UNITED STATES \\ DEPARTMENT OF THE INTERIOR \\ GEOLOGICAL SURVEY \\ WASHINGTON 25, D.C.}

$\mathrm{AEC}-4 / 1$

Alb 301950

Dr. Phillip L。 Merritt, Assistant Manager

Raw Matarials Operations

U. So Atomic Energy Cormission

P. O. Box 30, Ansonia Station

New York 23, New York

Dear Dr。 Merritt:

Enclosed for your information and distribution are five copies of Trace Elements Memorandum Report 34. "Radiometric scanning of collections of Keweenawan rocks of the Michigan copper district," by Wo . White, August 1950.

Other copies of this report are being distributed as indicated on the attached distribution sheet.

Sincerely yours,

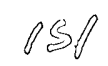

Esper S, Lansen, 3d

Acting Chief Goologist

Enclosures 5

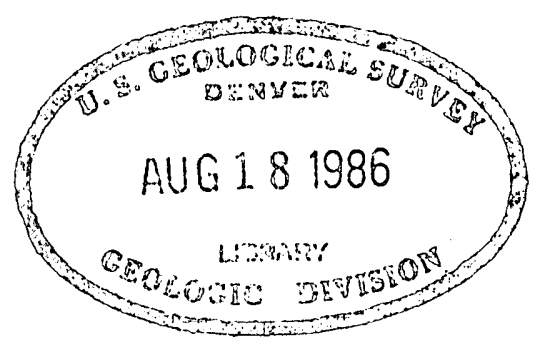


UNTTED STATES DFPARTHEIT OF TEE INTERIOR

GEOLOGICAI, SURVEY

RADIONETRIC SCANNING OF COLLECTIONS

OF KENEETANATIN ROCKS OF

THE MICHIGAN COPPER DISTRICT

by

W. S. White

August 1950

Trace Elementis Memorandum Report 34 


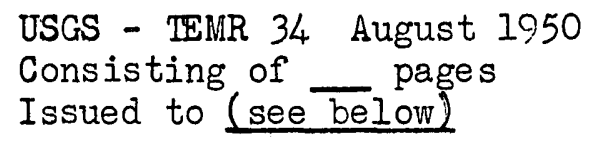

The distribution of this report is as follows:

2 copies ................ WEC, Washington, D. C. (J. C. Johnson)

5 copies ........... AEC, New York (P. L. Merritt)

1 copy ....................... Denver, Colo. (C. C. Towle, Jr.)

1 copy . ........... AEC, Spokane, Wash. (E. E. Thurlow)

1 copy .................... GEand Junction, Colo. (W. Fetzer)

13 copies . . . . . . . . . U. S. Geological Survey (including master copy) 


\section{Contents}

\section{Page}

Abstract................................................ 1

Introduction $\ldots \ldots \ldots \ldots \ldots \ldots \ldots \ldots \ldots \ldots \ldots \ldots \ldots \ldots \ldots \ldots \ldots \ldots \ldots \ldots$

Method of testing $\ldots \ldots \ldots \ldots \ldots \ldots \ldots \ldots \ldots \ldots \ldots \ldots \ldots \ldots \ldots \ldots \ldots \ldots . \ldots 2$

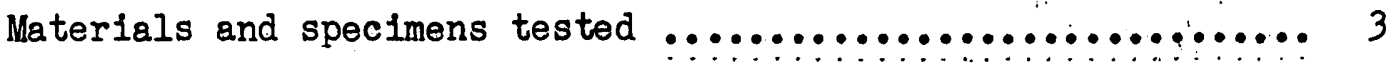

Arsenide-bearing fissures ........................... 3

Nonesuch shale $\ldots \ldots \ldots \ldots \ldots \ldots \ldots \ldots \ldots \ldots \ldots \ldots \ldots \ldots \ldots . . \ldots \ldots \ldots \ldots . . \ldots$

Calumet and Hecla, and Allouez conglomerates ............... 4

Gabbro and felsite .............................................: 4

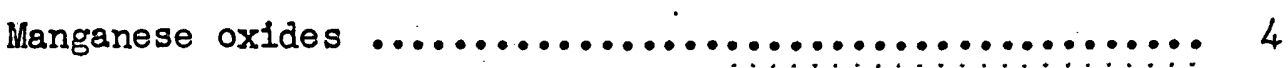

Geological Survey rock collection ................... 4

Drill Core ................................ 6

Conclusion $\ldots \ldots \ldots \ldots \ldots \ldots \ldots \ldots \ldots \ldots \ldots \ldots \ldots \ldots \ldots \ldots \ldots \ldots \ldots \ldots \ldots \ldots$ 


\title{
RADIOMETRIC SCANNING OF COLLECTIONS OF KEWEENAWAN ROCKS OF THE MICHIGAN COPPER DISTRICT
}

\author{
by \\ W. S. White
}

Abstract

Keweenawan rocks from the Michigan copper district were tested radiometrically during the period, June 2 to 15,1949 . The materials tested included drill core of the Calumet and Hecla Consolidated Copper Company. and rock and mineral specimens collected by that company and the U. S. Geological survey.

Tests of individual specimens failed to indicate the presence of sufficient radioactive material to produce a count of 25 percent above background. As the materials tested are believed to be representative of each of the rock types of the area, no further work in this area is recommended.

\section{Introduction}

Keweenawan rocks of the Michigan Copper district were tested radiometrically during the period June 2 to June 15, 1949, in connection with the Geological Survey's investigation of the copper deposits of the Keweenawan Peninsula, Michigan.

The reconnaissance was suggested in a letter of May 13, 1949, from T. M. Broderick of the Calumet and Hecla Consolidated Copper Company, in which he cited the occurrence of uranium with native copper in western sandstones. An attempt was made to test all the types of rocks and minerals of the Michigan copper district. In addition, six boxes of drill core from Keweenaw County, large numbers of mining samples, and the U.S. Geological Survey's collection of rocks of the district were tested. In this collection all types 
of vein-filling material commonly encountered in mine workings are represented by many hundreds of specimens.

\section{Method of testing}

Two types of tests were made: (1) Specific tests with the counter tube in contact with individual specimens of the most promising rocks; and (2) survey. tests made by scanning boxes of drill core and by making counts on bulk samples. In the specific tests, if the count was above background by more than one or two clicks per minute, the count was extended to two to eight minutes. Survey tests were made by holding the tube against one side of a box of specimens, by inserting it in the middle of the box, or by moving the tube slowly over a box of drill core. Boxed material was generally tested for two minutes, but some boxes were tested for eight minutes. Drill core was scanned at the rate of 12 to 15 feet of core per minute. Pauses of 15 seconds were made at local spots of apparent radioactivity. An empirically determined range for background counts was used as a reference for determining radioactivity. This range is given in the following table.

Deviation of background for different intervals of counting:

Minutes of counting

1

2

4
Maximum deviation from average

13 counts $/ \mathrm{mm}$

7 counts $/ \mathrm{mm}$

4 counts $/ \mathrm{mm}$

2 counts $/ \mathrm{mm}$
Maximum deviation as percent of average 
\lrcorner Background ranged from 26 to 32 counts per minute as determined by measurements for 8 minutes at various times during the period of the tests. The figures for 4 and 8-minute intervals are based on an average obtained during a 16-minute interval.

\section{Materials and specimens tested}

The materials that were tested included samples of arsenide-bearing fissures; the Nonesuch shale; the Calumet and Hecla, and Allouez conglomerates; orthoclase gabbro; extrusive felsite; and manganese oxide. In addition, tests were also made of samples of most of the rocks of the district as represented by the Goological Survey's collection, six boxes of Calumet and Hecla's core containing crossisections of copper-bearing and barren veins in Keweenaw County and 600 feet of core representing random samples of rocks of the district. Prior to the tests it was expected that the arsenide-bearing fissures and the carbonaceous Nonesuch shale might be the most promising rocks of the district.

\section{Arsenide-bearing fissures.--The arsenide-bearing fissures contain} copper arsenides, traces of cobalt and nickel, and abundant ankerite gangue. Thirty-five specimens of this material were tested individually for one minute with the counter tube in contact with the specimen. If the count exceeded background by 1 or 2 counts per minute, the counting interval was extended as described above. Only six specimens gave a count above background after 4 minutes but the count for all of them did not exceed background at the end of 8 minutes.

Nonesuch shale.-The Geological Survey's collection of specimens from the White Pine mine, representing all types of rock in the Nonesuch shale, was tested in bulk by laying the counter tube on each of six boxes in which the collection is housed, or by inserting the tube dow between 
the specimens. All the counts were within the range of deviation of background given in the table on page 2. In addition all the individual specimens were tested by counting for 15 seconds. Those that appeared to have a high counting rate in this interval were tested for as long as 8 minutes. Only one specimen had a counting rate 15 percent greater than background at the end of 8 minutes. Calumet and Hecla, and Allouez conglomerates,- Two specimens of Calumet and Hecla conglomerate weighing 4 or 5 pounds were tested for 8 minutes each and gave counts 21 percent and 12 percent above background. A box of Allouez conglomerate from the Boston and Albany (Franklin Jr.) mine dump gave a count of 21 percent above background; but counts made on the individual specimens, mostly small, were not significantly above background. These results suggest the presence of a small amount of radioactive material, which may be potassium, as potash feldspar is a major mineral constituent in the conglomerates.

Gabbro and felsite.- Tests on a box containing specimens of orthoclase gabbro from Mount Bohemia and on a small tray containing 4 or 5 pounds of specimens of extrusive felsite gave readings 19 percent above background. The radioactivity of individual specimens of the gabbro did not exceed background. These results are comparable to radioactivity measurements of the potash-rich conglomerates.

Manganese oxides.--Specimens from the dumps of some old manganese copper prospects containing manganese oxides gave counts no higher than the background average.

Geological Survey rock collection.-Tests were made on the U. S. 
Geological Survey's collection of rock specimens of the district. The collection is housed in about 120 powder boxes and in trays. The boxes were all tested as bulk samples by holding the tube against one end of the box for counting for intervals outlined under "Methods of testing." This survey has only statistical significance; as even a highly radioactive specimen at the far end of a box might not be detected. A 2inch vial of radioactive material supplied by Calumet \& Hecla Consolidated Copper Company gave a reading of about $.05 \mathrm{MR} / \mathrm{hr}$ at a distance of 1 foot from the tube on a table. When this vial was placed among the specimens in the middle of a powder box, the tube held at the end of the box was about 9 inches from the vial, and the instrument gave a reading of about $.05 \mathrm{MR} /$ hour. The count was much less, however, when the vial was placed at the far end of the powder box. As most of the rocks and minerals of the district are each represented by large numbers of specimens, however, there is little chance that all specimens of a given type would always be at the far end of a box, and a very good chance that more than one specimen of each type of material lies at the end at which the tube was held. Considered in terms of bulk rather than rock type, about a quarter of the collection was within 5 inches of the tube for at least one count, and half within 10 inches.

That part of the collection that is housed in trays was scanned by placing the counter for a few seconds in a number of positions in the tray and taking one-minute counts at any spot where there seemed to be above-average radioactivity。 
Drill core ${ }_{0}--$ Six boxes of Calumet and Hecla drill core from Keweenaw County, containing cross sections of copper-bearing and barren veins, were scanned as outlined under "Methods of testing." Rate-meter readings were no higher than those for the average background.

In addition to the core containing fissures, about 600 feet of other drill core were scanned as random samples of rocks of the district. This scanning yielded no count above average bäckground.

\section{CONCLUSION}

The representative character of large collections of the rocks described under the headings from the "Arsenide-bearing fissures" to "Drill core", inclusive, makes it extremely unlikely that significant amounts of radioactive material are present in any of the rocks or ore bodies in the district. The tests that were made do not preclude the occurrence of scattered veins containing pitchblende or other uranium ore in the district. If such veins exist, however, they must be correlated to the common veins and fissures of the district. There is, moreover, no evidence in the copper district of such veins derived from Keweenawan rocks, $n$ or are there any means now known for determining where they might be sought, if they do exist.

The tests made on Keweenawan rocks, all of which showed negative results, should be fair tests of the rocks and minerals of the whole Keweenawan province, with the possible exception of the Duluth gabbro and veins le ading from it. The Mount Bohemia gabbro, however, is ale. most identical chemically with the Duluth gabbro. Furthermore, it is 
generally agreed that the Duluth gabbro is merely an intrusive body of the same magma that gave rise to the Keweenawan flows. The common vein matter of the district is also generally conceded to have been derived ultimately from the same magna. The radiometric scanning Indicates the absence of sufficient radioactive material to warrant the assumption of any local concentrations in the Keweenawan rocks large enough to justify further search. 